Marcel Lizak

\title{
ROLA PRZYWÓDZTWA W KONCEPCJI LEAN MANAGEMENT
}

\begin{abstract}
Streszczenie: W rozdziale dokonano analizy zagadnienia przywództwa i jego roli w koncepcji Lean Management. Skoncentrowano się głównie na zasobach literatury krajowej i międzynarodowej. Przywództwo scharakteryzowano w aspekcie poszczególnych zadań, które wspomagają implementację koncepcji Lean Management. Lean Leadership jest nowym podejściem, które współtworzy przywództwo z zastosowaniem koncepcji Lean, która przyczynia się do uzyskania lepszych efektów końcowych. $\mathrm{W}$ podsumowaniu zaprezentowano wnioski dotyczące implementacji tej koncepcji w przedsiębiorstwach.
\end{abstract}

Słowa kluczowe: Lean Leadership, Lean Management, ciągłe doskonalenie, przywództwo

\section{Wprowadzenie}

Koncepcja Lean Management jest podejściem, które ma na celu osiągnięcie redukcji czasu realizacji poszczególnych projektów. Jednocześnie dostrzegając poszczególne determinanty takie jak: odpowiedni czas przezbrojeń (odpowiada za elastyczność system oraz organizacji produkcji masowej) [1], podniesienie poziomu efektywności procesów oraz jakość wpływając na implementację tej koncepcji. Ponadto powinno się zadbać o morale pracowników oraz określić rolę czynnika ludzkiego podczas identyfikacji celów jednostki i przedsiębiorstwa. Najistotniejszym elementem w Lean Management jest odniesienie się do alternatywnych rozwiązań podczas realizacji określonych celów w organizacji.

Lean Management jest kojarzony $\mathrm{z}$ sukcesem japońskiego przedsiębiorstwa pochodzącego z przemysłu samochodowego, gdzie pracownicy oraz przełożeni tworzą jeden zespół [2]. Prekursorem Lean Management stał się Taichii Ohno, który jest uznawany za ważną postać kojarzoną $\mathrm{z}$ tą koncepcją. Dokonał on możliwości operacjonalizaji poszczególnych czynności takich jak: płynność produkcji i system sugestii pracowniczych [3]. Japońska kultura identyfikuje miejsce powstania Lean Management oraz jej elementarne założenia o charakterze filozoficznym. Nie sposób wykluczyć rolę amerykańskich wpływów odnoszących się do obszaru zarządzania poszczególnymi czynnikami o charakterze fundamentalnym. Poniżej zaprezentowane determinanty posiadają zasadnicze oddziaływanie na otoczenie [3]:

- rola wybitnych liderów w historii Toyoty,

${ }^{1}$ mgr, doktorant Politechniki Częstochowskiej, marcellizak876@gmail.com, ORCID ID: 0000-0001$5841-7384$ 
- miejsce powstania Toyoty,

- założyciele rodziny Toyody,

- branża przemysłu motoryzacyjnego,

- istota rozwiązań organizacyjnych,

- jakość - Deming [1] - są to działania następujące po sobie w logicznym porządku realizujące zasadę ciągłego doskonalenia funkcjonowania przedsiębiorstwa,

- naukowe zarządzanie,

- rozwiązania produkcyjne.

H. Ford stał się symbolem naukowego zarządzania w Stanach Zjednoczonych [4]. Podejście jego miało na celu podniesienie poziomu efektywności i wydajności pracy $\mathrm{w}$ oparciu o zastosowanie poszczególnych metod organizatorskich. Kolejną przedstawicielem był F. W. Taylor, który podczas procesu implementacji poszczególnych czynności dokonał podziału planowania i produkcji, kładł nacisk na standaryzację pracy oraz redukcję czasu pracy [5].

Jednym z elementów dzięki, któremu rozpoznajemy koncepcję Lean Management jest System Produkcyjny Toyoty. W oparciu o niego sformułowano Just in Time, który dotyczył filozofii automtaycznego rozpoznawania oraz procesu eliminacji błędów i marnotrawstwa [6]. System pierwszego filaru został zaimplementowany już w latach 30 . XX wieku. Taichii Ohnno uważał, że istnieje potrzeba zmian $\mathrm{w}$ procesie produkcji poprzez otrzymanie samochodów o jak najwyższej jakości przy jak najniższym poziomie kosztów. Zidentyfikował obszary koncepcji szczupłego zarządzania takie jak: redukcja strat, motywacja, partycypacja oraz kwalifikacja pracowników organizacji.

Proces Just in time [7] określa, że produkowane są tylko części potrzebne w danym okresie lub jednostce czasu. Źródło tej koncepcji ma miejsce w momencie pozyskania surowców do dostarczenia wyrobu gotowego do klienta[8].

Natomiast Jidoka [7] jest objaśniana jako automatyzacja z czynnikiem ludzkim dotyczącym podkreślania i wizualnego przedstawienia problematyki. Dodatkowo został wprowadzony aspekt jakości podczas procesu produkcyjnego, który przyczynia się do zatrzymania linii produkcyjnej oraz wykrycia wadliwego wyrobu gotowego.

Celem rozdziału jest analiza zagadnienia na tle literatury przedmiotu terminologii dotyczącej Lean Management oraz Lean Leadership, które oddziałują na poszczególne etapy koncepcji szczupłego zarządzania w organizacji. W artykule poruszono problematykę dwóch istotnych terminów takich jak przywództwo i przywódca. Jednocześnie ukazując aktualny obszar do dalszych etapów rozwoju koncepcji Lean w przywództwie oraz jego otoczeniu organizacyjnym. Ponadto powinna zostać wykonana analiza terminologii przywództwa w literaturze. 


\section{Istota pojęcia przywództwa}

Przywództwo określa się jako oddziaływanie przywódców na osoby grupy nieformalnej, dzięki czemu zachowują się oni tak, jak podwładni kierowani przez przełożonego w obrębie organizacji rzeczywistej, ale nie odbiegającej od założeń grupy formalnej. Przywództwo jest kreowane na podstawie autorytetu posiadanego przez przywódcę odwołując się do autorytetu osobistego lub technicznego, nie zaś o autorytet władzy[9].

Termin „przywództwo” nie jest przejrzyste zarówno w teorii, jak i praktyce zarządzania. Pojęcie przywództwa określane jest jako forma władzy oraz jest pokrewne $\mathrm{z}$ pojęciem kierowanie. W rzeczywistości organizacyjnej kierownictwo dostrzega dwuaspektowy pogląd na poniższą problematykę. Pierwszym elementem są treść i metoda wykonywania poszczególnych spraw. Są one zdefiniowane w bardzo szerokim zakresie różnice indywidualne są małoistotne natomiast akty przywództwa są postrzegane jako elementy dobrowolne. Ponadto w najgorszej możliwości interpretowane są jako niesubordynacja. Podczas osiągania pozytywnych rezultatów przez organizację kierownictwo nagradza formalnych przywódców, a podczas niepowodzenia dokonuje konstruktywnej krytyki.

W latach trzydziestych ubiegłego stulecia w USA przeprowadzono badania, co do sposobu w jaki stają się oni przywódcami- jednocześnie termin „Leadership” stosowano w kontekście procesów zachodzących w poszczególnych organizacjach oraz grupach formalnych. Współczesne zarządzanie coraz częściej odnosi się do problematyki przywództwa dzięki, której można zauważyć zdywersyfikowanie terminologii przywództwa. Ponadto podjęto próbę systematyzacji pojęć, które ułatwią rozwój tego terminu w naukach o zarządzaniu. W literaturze przedmiotu można dostrzec kolejne definicje przywództwa [10-12]:

- J.C.Maxwell-,,wywieranie wpływu”,

- S.P. Robbins- „wpływanie na grupę, aby osiągnęła określone cele”,

- G.R. Terry- „wywieranie wpływu na ludzi, by chętnie dążyli do osiągnięcia grupowych celów",

- J.C. Willams, A.J. Dubrin, H.L. Siska - „procesem wpływania na innych, aby osiągnąć określone cele w konkretnych sytuacjach bez wykorzystywania technik opartych nadmiernie na wymuszaniu grupowych celów",

- R. Rutka - „tworzenie stanów emocjonalnych uczestników organizacji, skłaniających ich do zaangażowanego realizowania celu wraz z przywódcą, który on sformułował i do osiągnięcia, którego ich pociąga siłą swojego oddziaływania", 
- R.M. Stogdilla- interpretuje przywództwo zarówno jako proces oraz właściwość. Proces przywództwa odnosi się do nieprzymuszonego ukierunkowaniu i koordynowaniu poszczególnych osób funkcjonujących codziennie w organizacji dla realizowania skonkretyzowanych celów. Przywództwo jako właściwość jest to zbiór cech osobowościowych przydzielanych tym, których postrzegano jako stosujących oddziaływanie z pozytywnym efektem końcowym.

Paradygmat przywództwa, który zastosowano w oparciu o zasady powinien zostać scharakteryzowany. Pierwszą $\mathrm{z}$ reguł są naturalne prawa, a następną podstawowe wartości społeczne, które odnosiły się do każdej istotnej cywilizacji [13]. Objawiają się one poprzez zastosowanie norm, ideałów, idei oraz nauk. Przyczyniają się do uzyskania spełnienia, szlachetności czy inspiracji. Aspekt ten odnosi się do przeprowadzenia dyskusji na temat misji, roli czy wizji organizacji. M. Hatch, M. Kostera, A. Koźmiński formułują przywódców w trzech rolach: kapłanów (wartości i wierzenia), artystów (innowatorzy) i menedżerów (podejmujących decyzje) [14]. Są to ciągłe zmiany oddziałujące na zdynamizowanie konkretnych obszarów. Autorzy uważali, że jedynie artyści potrafią sobie poradzić w podanej sytuacji. Natomiast E.H. Schein ujmuje pojęcie przywództwa jako analizę $w$ aspekcie umiejętności zmiany $\mathrm{w}$ zakresie kultury organizacyjnej [15]. Kultura organizacyjna opiera się na wieloaspektowym podejściu do jej interpretacji. Podział nastąpił według otoczenia organizacji o charakterze wewnętrznym i zewnętrznym [16].

Przywództwo jest określone jako proces oraz pewna właściwość [17]. Proces jest scharakteryzowany jako wykonywanie tego, co generalnie wykonują przywódcy przywództwo odnosi się do osiągania wpływu z zamiarem kształtowania celów grupy lub organizacji, odpowiednie motywowanie pracowników oraz współtworzenie kultury organizacyjnej. Właściwością staje się przewodzenie zestawem cech przypisywanym poszczególnym jednostkom, których określa się mianem przywódców. Przywódcy to osoby, które umiejętnie oddziałują na zachowania innych oraz osoby akceptowane przez innych $\mathrm{w}$ roli liderów. Truman nakreślił cztery wnioski, które oddawały istotę pojęcia [18]:

1. Przywództwo odnosi się do innych ludzi, podwładnych lub zwolenników. Odpowiednie podporządkowanie się informacją ze strony przywódcy - członkowie organizacji mają swój udział podczas wypracowania aktualnej pozycji konkurencyjnej oraz pozwalają na zastosowanie procesu przewodzenia.

2. Występuje niejednolity podział władzy miedzy przywódcą i uczestnikami grupy. Osoby tworzące grupę nie są jej do końca pozbawieni. Również przyczyniają się do wielu zróżnicowanych sposobów dotyczących zdywersyfikowania poszczególnych działań grupowych. 
3. Pozyskanie kolejnej umiejętności jaką jest zastosowanie różnych postaci władzy do oddziaływania na różne sposoby wpływu na zachowanie kolejnych osób.

4. Ostatni aspekt jest to podsumowanie trzech powyższych, które przyczyniają się do połączenia przywództwa z wartościami. Przywództwo moralne wspomaga dostarczenie wymaganej ilości informacji o różnych sposobach funkcjonowania $\mathrm{w}$ celu podjęcia racjonalnych wyborów podczas reakcji na propozycje przywódcy.

\section{Charakterystyka przywódcy}

Osoba kandydująca do roli przywódcy bądź lidera powinna posiadać cechy o charakterze genetycznym, które przyczynią się do usprawnienia procesu zarządzania w organizacji. Badacze w zakresie przywództwa podkreślili, że można zidentyfikować je dzięki analizie osobowości danego kandydata. Uważano, że na przywódcę nie można wyrosnąć, lecz trzeba się z tym urodzić. Poniżej zaprezentowano w ujęciu tabelarycznym zbiór cech osobowościowych, które definiują kandydata na przywódcę do skutecznego lidera.

Tabela 1. Charakterystyka osoby przywódcy [18]

\begin{tabular}{|c|c|}
\hline Autor zestawienia & Listy cech \\
\hline R.L. Katz(1954) & $\begin{array}{ll}\text { - } & \text { umiejętności społeczne } \\
\text { - } & \text { umiejętności techniczne } \\
\text { - } & \text { umiejętności koncepcyjne }\end{array}$ \\
\hline K. Obłój (1974) & $\begin{array}{ll}\text { - } & \text { pewność siebie } \\
\text { - } & \text { ambicje } \\
\text { - } & \text { orientacja na sukces } \\
\text { - } & \text { asertywność } \\
\text { - } & \text { odporność na stres } \\
\text { - } & \text { upór i stanowczość } \\
\text { - } & \text { odwaga } \\
\text { - } & \text { inteligencja }\end{array}$ \\
\hline R.M.Stogdill (1974) & $\begin{array}{l}\text { - } \text { silne dążenie od odpowiedzialności i wykonywania zadań } \\
\text { - } \text { energia i wytrwałość w dążeniu do celu } \\
\text { - } \text { przedsiębiorczość } \\
\text { - } \text { kreatywność } \\
\text { - } \text { pewność siebie } \\
\text { - } \text { skłonność do akceptowania konsekwencji podejmowanych } \\
\text { decyzji } \\
\text { - umiejętność panowania nad stresem } \\
\text { - } \text { umiejętność tolerowania opóźnień } \\
\text { zdolność do oddziaływania na zachowania innych osób }\end{array}$ \\
\hline
\end{tabular}


- umiejętność strukturalizowania systemów interakcji społecznych

Źródto: [18]

Istotną zmianą, jaka została wykonana w zakresie przywództwa jest zgodna instrukcjami P. Druckera. Dla tego autora przywództwo było priorytetową sprawą. Według niego przywództwo nie powinno zostać stworzone ani promowane. $Z$ reguły przywództwa nie można jednocześnie nabyć poprzez naukę czy analizę literatury przedmiotu. Dopiero po 1985 roku Drucker po wielu dyskusjach z menedżerami ustalił, że liczba „urodzonych liderów” jest niewielka. Kolejnym poglądem jest to, że przywództwa należy się nauczyć [19].

\section{Lean Leadership - szczupłe przywództwo}

Lean Leadership zdefiniowano jako zestaw kompetencji, praktyk oraz zachowań podczas skutecznej implementacji koncepcji Lean Management[24]. Dombrowski i Mielke zaprezentowali model o charakterze koncepcyjnym dotyczącym zintegrowanego modelu przywództwa typu Lean. Ten model składa się z pięciu elementarnych pojęć, a są to [20-22]:

- Kultura doskonalenia - jest to zbiór zachowań i postaw, które są źródłem ciągłego dążenia do doskonałości. W momencie, gdy liderzy starają się zapobiegać awariom, wtedy interpretowane jest to jako szansa na dalsze doskonalenie umiejętności.

- Samodoskonalenie- jest to zmiana dotycząca ciągłego doskonalenia, które wymaga konkretnych umiejętności przywódczych, (wrodzone lub nabytych).

- Kwalifikacja pracowników- odnosi się do popularyzacji idei jeszcze większego zaangażowania pracowników $\mathrm{w}$ życie organizacji, jak i identyfikacji z przedsiębiorstwem oraz ciągłego uczenia się nowych elementów niezbędnych do rozwiązania poszczególnych problemów.

- Gemba kaizen - celem tego elementu jest dotarcie liderów do miejsc w którym tworzona jest wartość. Lider powinien znaleźć miejsce w organizacji do którego dotrze i gdzie zachodzić będą procesy o charakterze wartościującym. Spacery lidera po obszarze Gemba w organizacji są tożsame z uznaniem lidera dla pracy poszczególnych pracowników. Lean Leader ma za zadanie przestrzegać pięciu złotych zasad „gemba”.

- Hoshin kanri - to „zarządzanie celami” lub „wdrażanie polityki”. Jest to metoda dopasowywania celów do potrzeb klienta na wszystkich poziomach. Hoshin Kanri jest symbolem systemowego podejścia do modyfikacji, łącząc wszystkie 
zespoły, aby cel nadrzędny(strategiczny) został zrealizowany. Lean Leaders opracowują strategię oraz cele przedsiębiorstwa w horyzoncie długoterminowym.

Powyższe czynniki przyczyniają się do elementarnych cech koncepcji Lean Management jako aktywnej jednostki w szczupłym środowisku. Zespoły w których są zatrudnieni uczestnicy organizacji identyfikują się z przedsiębiorstwem oraz dbają o ciągłe doskonalenie umiejętności.

W literaturze przedmiotu wyróżniono trzy rodzaje przywództwa [23,24]:

- Przywództwo transformacyjne - miejsce gdzie przywódca określa potrzebną zmianę poprzez inspirację i wykonuje modyfikacji z dużym zaangażowaniem.

- Wzmocnienie przywództwa - jest to wywieranie wpływu na innych poprzez rozwijanie i wzmacnianie zdolności przywódczych we własnym zakresie.

- Służebne przywództwo - zostaje wykazane podobieństwo pomiędzy przywództwem służebnym, a rolą lidera w Systemie Produkcyjnym Toyoty, który tworzy wartość dzięki służeniu swojemu zespołowi. Pracownicy tworzący wartość dodaną są „na górze”, a „ uniżeni” liderzy powinni udowodnić swoją wartość wykazując się pomocą i wsparciem dla swoich zespołów.

W myśl tej koncepcji podniesiono poziom odpowiedzialności pracowników oraz zwiększono rolę pracownika w życiu organizacji. Ponadto liderzy zwracają uwagę na nieustanne zwiększanie poziomu kwalifikacji pracowników w przedsiębiorstwie [23]. Następnie przejrzyste zaprezentowanie celów organizacji, które powinny być dostępne dla poszczególnych uczestników życia organizacji na każdym poziomie. $\mathrm{Z}$ tego powodu należy sformułować zrozumiałe cele, które będą jednoznaczne dla poszczególnych osób. Skutkować to będzie wyższym poziomem zaangażowania $\mathrm{w}$ otoczenie wewnętrzne i zewnętrzne organizacji. Poszczególne uwarunkowania kulturowe będą istotnym czynnikiem podczas procesu tworzenia kultury przywództwa.

Kultura przywództwa została ukształtowana w oparciu o osobowości, wartości oraz doświadczenie zdobyte poprzez założycieli organizacji. Przywództwo, które było postrzegane przez reprezentantów Toyoty miało na celu gotowość do realizacji nieosiągalnych celów. Przywództwo w Toyocie jest doskonałym przykładem instytucjonalnego podejścia do tego obszaru. Aspekt kulturowy przywództwa może zostać zaprezentowany jako proces $w$ wymiarze Lean Leadership. Mann przeprowadził jedno z pierwszych badań nad rolą lidera w zakresie koncepcji Lean [25]. Dzięki niemu zostało rozpowszechniona rola przywództwa jako procesu w kontekście Lean Leadership. 


\section{Podsumowanie}

W artykule zaprezentowano rezultaty badań literaturowych zagadnień: przywództwa, współczesnej koncepcji zarządzania Lean Management, koncepcji Lean Leadership oraz przedstawienie istoty zjawiska ciągłego doskonalenia. Współcześnie w przedsiębiorstwach dużo jest informacji na temat przywództwa oraz sposobów jego udoskonalania. W artykule zaprezentowano nowe podejście, jakim jest Lean Leadership. Przywództwo, a w szczególności „szczupłe przywództwo" będzie przyczyniało się do większej wydajności przedsiębiorstwa. Czytelnik posiadający taką wiedzę ma okazję docenić również nieustanne doskonalenie się jako uczestnika organizacji.

W koncepcji Lean Management zjawisko o którym wspomniano powyżej ma istotne znaczenie dla dalszego rozwoju. Należy zadbać, aby wszystkie determinanty, warunki, instrukcje zostały spełnione celem uzyskania skutecznej, efektywnej implementacji w myśl „,szczupłego zarządzania”.

Dokonano charakterystyki elementarnych pojęć przywództwa oraz cech osobowych przywódcy jako kandydata idealnego. Opisano osobę na tle wybranych charakterystyk znajdujących się w literaturze przedmiotu. Świadomość czytelników wzrasta dzięki doskonaleniu tej dziedziny oraz nieustannym jej rozwoju.

\section{Literatura}

[1] Ulewicz R., Mazur M.: Doskonalenie transportu wewnętrznego z wykorzystaniem koncepcji Lean-Studium przypadku. Przegląd Organizacji, nr 7, 2015, s.6-13

[2] Nowosielski S., Osbert-Pociecha G.: Lean Management jako ogólna koncepcja transformacji przedsiębiorstw. [w:] Podstawy nauki o przedsiębiorstwie. Lichtarski J. (red.), Wydawnictwo Akademii Ekonomicznej, Wrocław 2007, s. 325-326.

[3] Parkes A.: Kulturowe uwarunkowania Lean Management. Difin, Warszawa 2017.

[4] Ford H.: Dziś i jutro. Wydawnictwo ProdPress.com, Wrocław 2007.

[5] Dennis P.: Lean Production Simplified. Wydawnictwo: Productivity Press, New York 2007.

[6] Ulewicz R., Jelonek D., Mazur M.: Implementation of Logic Flow in Planning and production control. Management and Production Engineering Review, vol. 7, No 1, March 2016, pp.89-94

[7] Ohno T.: System Produkcyjny Toyoty. Więcej niż produkcja na duża skalę. Wydawnictwo: ProdPress.com, Wrocław 2008.

[8] Womack J.P., Jones D.T.: Lean Thinking - szczupte myślenie. Wydawnictwo ProdpressPublishing.com, Wrocław 2012. 
[9] Pszczołowski T.: Mała encyklopedia prakseologii $i$ teorii organizacji $i$ zarzadzania. Zakład Narodowy im. Ossolińskich, Wrocław 1978.

[10] Kuc B.R.: Od zarządzania do przywództwa. Wydawnictwo Menedżerskie PTM, Warszawa 2004.

[11] Czermiński A., Czerska M., Nogalski B., Rutka R., Apanowicz J., Zarządzanie organizacjami., TNOiK, Torun 2001.

[12] Robbins S.: Zachowania $w$ organizacji. Polskie Wydawnictwo Ekonomiczne, Warszawa 2004.

[13] Covey S.R.: Zasady skutecznego przywództwa. Dom Wydawniczy REBIS Sp. z o.o. Poznań 1997.

[14] Hatch M., Kostera M., Koźmiński A.: Trzy oblicza przywództwa. Wydawnictwa Akademickie i Profesjonalne, Warszawa 2010.

[15] Schein E.H.: Organizational Culture and Leadership. John Wiley \& Sons, New York 2004, s. 11.

[16] Winch S.: Substytuty przywództwa w przedsiębiorstwie- koncepcja teoretyczna i jej implikacje praktyczne. Oficyna Wydawnicza SGH, Warszawa 2016.

[17] Griffin R.W.: Podstawy zarzadzania organizacjami. Wydawnictwo Naukowe PWN, Warszawa 2004.

[18] Kuc B.R.: Od zarządzania do przywództwa. Wydawnictwo Menedżerskie PTM, Warszawa 2004.

[19] Hesselbein F., Goldsmith M., Beckhard R., Lider przyszłości. BusinessPress, Warszawa 1997.

[20] Poksinska B., Swartling D., Drotz E.: The daily work of Lean leaders - Lessons from manufacturing and healthcare. Total Quality Management \& Business Excellence, 24(7-8), 886 -898. doi:10.1080/14783363.2013.791098.

[21] Dombrowski, U., Mielke, T.: Lean leadership - fundamental principles and their application. Procedia CIRP, Vol. 7, s. 569-574.

[22] Imai M.: Gemba kaizen. Zdroworozsądkowe, niskokosztowe podejście do zarządzania. Wydawnictwo MT Biznes, 2006.

[23] Assen v. M.: Exploring the impact of higher management's leadership styles on Lean management. Total Quality Management, 2018 vol. 29, No. 11, 1312-1313, https://doi.org/10.1080/14783363.2016.1254543.

[24] Liker K.J., Convis L.G.: Droga Toyoty do lean leadership - osiagnięcie i utrzymanie doskonałości dzięki ksztaltowaniu przywódców. MT Biznes, 2012.

[25] Mann D.: Creating a lean culture: Tools to sustain lean conversions. Productivity Press, New York, 2010. 


\title{
THE ROLE OF LEADERSHIP IN LEAN MANAGEMENT CONCEPT
}

\begin{abstract}
The chapter analyzes the issue of leadership and its role in the Lean Management concept. The focus was mainly on the resources of national literature and international. Leadership has been characterized in the aspect of individual tasks that support the implementation of the Lean Management concept. Lean Leadership is a new approach that co-creates leadership with the Lean concept that contributes to better final results. The summary presents conclusions regarding the implementation of this concept in enterprises.
\end{abstract}

Key word: Lean Leadership, Lean Management, continious improvement, leadership.

Data przestania publikacji do Redakcji: 07.12.2018

Data akceptacji publikacji przez Redakcję: 15.01.2019

DOI: 10.30657/qpi.2019.10.01 